\title{
SEA CURRENTS OFF THE NORTHUMBERLAND COAST
}

\author{
By Frank Evans
}

The Dove Marine Laboratory, Cullercoats

(Text-fig. I)

The non-periodical currents off the southern Northumberland coast are in general weak and variable and can with safety be ignored by the prudent navigator. For the student of the region's ecology, however, they are of greater significance, and it is of some importance that as exact a knowledge as possible of their speed and direction should be available. The present account is concerned with water movements close to the surface a mile or so offshore; deep currents, it is hoped, will form part of a separate study.

Earlier investigations have usually formed part of much wider surveys in the North Sea and the results have tended to be rather generalized for the small region between the River Tyne entrance $\left(55^{\circ}\right.$ or' N., $\mathrm{I}^{\circ} 24^{\prime}$ W.) and Newbiggin Point $\left(55^{\circ} \mathrm{II}^{\prime} \mathrm{N} ., \mathrm{I}^{\circ} 3 \mathrm{O}^{\prime} \mathrm{W}\right.$.) at present under consideration. Perhaps in consequence of this, different workers have produced conflicting results, although the work of Tait in particular has shown (Tait, 1937) that there may be considerable seasonal and even yearly fluctuations in the currents of the northern North Sea.

The main question at issue is whether the residual current flows along the Northumberland coast in a southerly or a northerly direction. A few instances of the differing conclusions reached will illustrate this. Fulton (1897), deriving his conclusions from drift bottle recoveries, held that it ran to the southward. Böhnecke, quoted by Meek (1926), and basing his conclusions on salinity curves, believed that it ran to the northward. Meek himself, in a paper in which he described the charting of the North Sea currents as 'the most fundamental problem of all' (in relation to fisheries biology), strongly refuted Böhnecke's conclusions. Like Fulton he believed in a southerly current and offered in evidence replies to a letter he sent to fishery officers, etc., up and down the coast inquiring whether, in their region, the ebb or flood ran the stronger. This appeal to common observation brought him a response from Northumberland stating that 'the flood tide is the stronger, the current going in a southerly direction'. But he failed to ask an equally important question, whether the ebb or flood ran the longer, and his argument is the weaker for this omission.

Tait's results, based on numerous drift bottle returns, were more complex. 
His final chart (1937) indicated a southerly drift about 15 miles offshore and a northerly counter-current running closer inshore. However, he remarked earlier (1930) that the correspondence between superficial water displacement and wind direction and velocity, particularly in shallow water areas adjacent to land may at times be very close. Since the prevailing winds on the Northumberland coast are westerlies this suggests, allowing for Coriolis force, a mean vector current in the shallow, coastal waters running approximately south-east.

In view of these differing accounts it is difficult to decide from the literature alone what is the true nature of the residual currents off Northumberland. In April I956 I began a survey in the hope of providing sufficient information from purely local waters to solve this problem. The method I employed was the old and well tried one of following the movements of a free-floating buoy having little windage, and plotting its track. As in all direct methods of measuring currents in the North Sea it was necessary for each observation to extend over a period of at least half a lunar day so that tidal effects could be eliminated. Observations were begun at various states of tide and continued for between $\mathrm{I}_{2}$ and $\mathrm{I}_{3} \mathrm{~h}$, the exact period to be spent tracking the buoy being determined from an inspection of the tide tables.

The buoy used was a fisherman's dan buoy to which was attached a drogue to reduce leeway. During the work a number of drogues were lost and because of this they were progressively strengthened in construction. In particular it was found that the connexion between buoy and drogue was subjected to considerable stress in heavy weather, which broke wires and opened shackles. In its most recent form (Fig. I) the buoy had spliced round it a short sling of 2 in. rope and to this sling was shackled $\mathrm{I} 4 \mathrm{ft}$. of $\mathrm{I}$ in. circumference wire. The wire was in turn shackled to an eyebolt in the bottom of the drogue. The drogue itself was in the form of an open ended box whose framework consisted of four wooden uprights each $4 \mathrm{ft}$. 6 in. by 2 in. by 2 in., and diagonal bars of steel $5 \mathrm{ft}$. long and $\frac{1}{2}$ in. in diameter at each end. Details of these diagonals are shown in Fig. I. The drogue was given a covering of no. 4 canvas.

The effective depth at which the current was measured by this instrument was assumed to be about $12 \mathrm{ft}$., i.e. the depth of the mid-point of the drogue. The effects of water movement on the buoy and wire were disregarded since it was felt that they would not be significantly different from those acting on the drogue. Consideration was, however, given to the effect of wind action on the buoy and this will be referred to later. In fact, the effect was negligible.

At sea the buoy's position was fixed every $45 \mathrm{~min}$. by horizontal and vertical sextant angles of conspicuous marks ashore. At the time of each fix the force and direction of the wind were estimated, short notes were made on the weather and state of the sea, and a sounding was taken. Owing to the proximity of the coast positions were accurate to within at least $0 . \mathrm{I}$ mile and usually much better.

From April r956 nineteen complete runs were made with the free-floating 
buoy over a period of 12 months. The incomplete run of 4 December 1956 has also been included, an estimate being made of the last $2 \mathrm{~h}$ of the run. The observations were spread as evenly as possible over the year and at least one

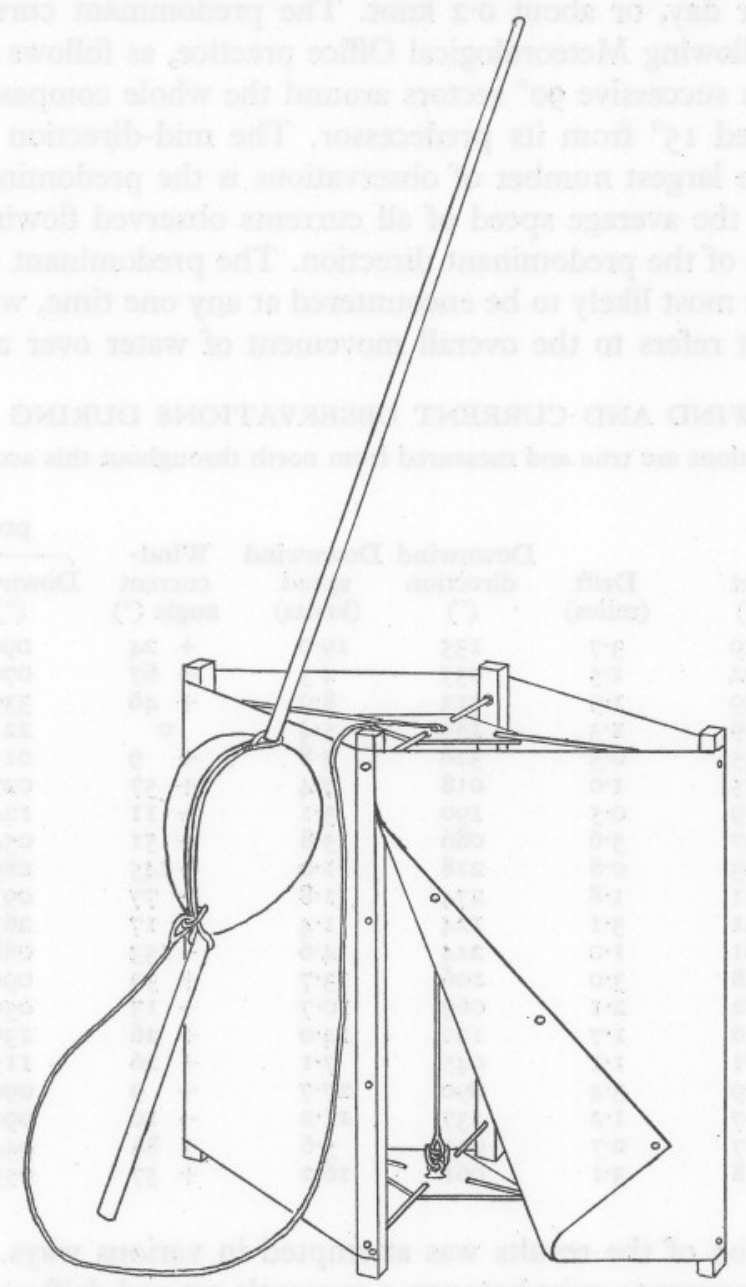

Fig. I. Diagram of the buoy and drogue used in the investigations. A flap of canvas is raised to show the attachment of the wire to the drogue.

run was made in each month except February 1957. As far as practicable the work was conducted in all states of weather; it should be noted, however, that projected runs were cancelled on days with strong north-easterly winds when the Northumberland coast becomes a lee shore.

From the results obtained (Table I) certain values may immediately be calculated. First, the mean vector current or resultant direction and speed 
works out at $\mathrm{II}^{\circ}{ }^{\circ}$ and $\mathrm{I} \cdot 30$ miles per half lunar day or about $0 \cdot \mathrm{I}$ knot. Secondly, the mean vector wind during the observations is $273^{\circ}, 5.4$ knots. Thirdly, the predominant direction and speed of current is $120^{\circ}$ and 2.5 miles per half lunar day, or about 0.2 knot. The predominant current has been calculated, following Meteorological Office practice, as follows: observations are totalled in successive $90^{\circ}$ sectors around the whole compass, each sector being displaced $15^{\circ}$ from its predecessor. The mid-direction of the sector containing the largest number of observations is the predominant direction. The speed is the average speed of all currents observed flowing within $45^{\circ}$ on either side of the predominant direction. The predominant current refers to the current most likely to be encountered at any one time, while the mean vector current refers to the overall movement of water over a period.

\section{TABLE 1. WIND AND CURRENT OBSERVATIONS DURING THE YEAR}

Directions are true and measured from north throughout this account

\begin{tabular}{|c|c|c|c|c|c|c|c|}
\hline \multirow[b]{2}{*}{$\begin{array}{c}\text { Date } \\
\text { I956-7 }\end{array}$} & \multirow[b]{2}{*}{$\begin{array}{l}\text { Set } \\
\left({ }^{\circ}\right)\end{array}$} & \multirow[b]{2}{*}{$\begin{array}{c}\text { Drift } \\
\text { (miles) }\end{array}$} & \multirow[b]{2}{*}{$\begin{array}{l}\text { Downwind } \\
\text { direction } \\
\left({ }^{\circ}\right)\end{array}$} & \multirow[b]{2}{*}{$\begin{array}{l}\text { Downwind } \\
\text { speed } \\
\text { (knots) }\end{array}$} & \multirow[b]{2}{*}{$\begin{array}{l}\text { Wind- } \\
\text { current } \\
\text { angle }\left(^{\circ}\right)\end{array}$} & \multicolumn{2}{|c|}{$\begin{array}{c}\text { Winds in } \\
\text { preceding } 24 \mathrm{~h}\end{array}$} \\
\hline & & & & & & $\begin{array}{c}\text { Downwind } \\
\left({ }^{\circ}\right)\end{array}$ & $\begin{array}{l}\text { Speed } \\
\text { (knots) }\end{array}$ \\
\hline 3 Apr. & I59 & 3.7 & I35 & 19.0 & +24 & 090 & $4 \cdot I$ \\
\hline I6 Apr. & 102 & $1 \cdot 5$ & 035 & 2.5 & +67 & 076 & 2.6 \\
\hline 20 Apr. & 359 & $I \cdot 9$ & 313 & 8.0 & +46 & 339 & $3 \cdot 3$ \\
\hline 25 Apr. & I89 & $r \cdot 3$ & 189 & 5.4 & 0 & 221 & 3.8 \\
\hline 2 May & 335 & 0.5 & 326 & 5.8 & +9 & OII & 4.0 \\
\hline 3 May & 075 & $I \cdot 0$ & or 8 & $7 \cdot 4$ & +57 & 027 & $2 \cdot 8$ \\
\hline I4 June & I79 & 0.5 & I90 & $3 \cdot I$ & - II & 124 & $6 \cdot 7$ \\
\hline I9 June & 137 & $5 \cdot 6$ & 086 & I5.8 & +51 & 054 & $6 \cdot 9$ \\
\hline 24 July & 003 & 0.8 & 218 & $I \cdot O$ & +145 & 089 & $5 \cdot 1$ \\
\hline 27 July & 351 & $I \cdot 8$ & 274 & $I \cdot 8$ & +77 & 097 & II.9 \\
\hline 7 Aug. & $\mathrm{I} 4 \mathrm{I}$ & $3 \cdot 1$ & 124 & I. 4 & +17 & 263 & $I \cdot 3$ \\
\hline 9 Aug. & 061 & $1 \cdot 0$ & 214 & $4 \cdot 6$ & -153 & 088 & $6 \cdot 5$ \\
\hline I3 Sept. & 138 & $3 \cdot 0$ & 106 & r3.7 & +32 & 090 & 6.5 \\
\hline 23 Oct. & 082 & $2 \cdot 1$ & 069 & 10.7 & +13 & 050 & II $\cdot 4$ \\
\hline 26 Oct. & I56 & $\mathrm{I} \cdot 7$ & 130 & 14.0 & +26 & 136 & $17 \cdot 3$ \\
\hline I3 Nov. & 071 & $\mathbf{I} \cdot \mathbf{I}$ & 045 & $7 \cdot 1$ & +26 & II5 & $8 \cdot 0$ \\
\hline 4 Dec. & 099 & $3 \cdot 4$ & 090 & $27 \cdot 7$ & +9 & 090 & 20.0 \\
\hline Io Jan. & 127 & $1 \cdot 2$ & I37 & II $\cdot 2$ & - Io & 090 & I 4.7 \\
\hline 22 Jan. & 087 & 0.7 & 003 & $5 \cdot 6$ & +84 & 044 & $9 \cdot 7$ \\
\hline 27 Mar. & II 8 & $3 \cdot 1$ & $06 \mathrm{I}$ & $16 \cdot 2$ & +57 & 055 & $7 \cdot 6$ \\
\hline
\end{tabular}

Interpretation of the results was attempted in various ways. No obvious relationship appears to exist between a current's set and drift and the moon's phase or the tidal range at the time of observation. Similarly, there is no clear relationship between a current and the departure of a tide from its predicted level as measured on a tide gauge at the River Tyne entrance. It remains to be seen whether two tide gauges widely separated would reveal a slope of the sea and hence a current-generating force. Density differences in the region are in general too small to cause horizontal currents of any importance.

The only valid relationship revealed by the results appears to be that between current and wind. Currents are listed in Table I against the direc- 
tions towards which the winds blew (henceforward called downwinds), obtained from the trigonometric summation of the $\frac{3}{4}$-hourly wind observations. Column 6 of this table shows the difference in degrees between current set and downwind, marked positive if the current ran to the right of downwind and negative if it ran to the left. Columns 4 and 6 are rearranged in Table 2 with downwinds increasing clockwise from north. It will be seen that the current ran consistently into the quadrant to the right of downwind except in the five downwind records $137^{\circ}$ to $218^{\circ}$; these records are anomalous and will be dealt with later. The remaining currents show a mean deflexion of $40^{\circ}$

TABLE 2. DOWNWIND DIRECTIONS AND WIND-CURRENT ANGLE

$\begin{array}{cccc}\begin{array}{c}\text { Downwind } \\ \left({ }^{\circ}\right)\end{array} & \begin{array}{c}\text { Wind- } \\ \text { current } \\ \text { angle } \\ \left({ }^{\circ}\right)\end{array} & \begin{array}{c}\text { Downwind } \\ \left({ }^{\circ}\right)\end{array} & \begin{array}{c}\text { Wind- } \\ \text { current } \\ \text { angle } \\ \left({ }^{\circ}\right)\end{array} \\ 003 & +84 & 130 & +26 \\ 018 & +57 & 135 & +24 \\ 035 & +67 & 137 & - \text { I0 } \\ 045 & +26 & 189 & -0 \\ 061 & +57 & 190 & -11 \\ 069 & +13 & 214 & -153 \\ 086 & +51 & 218 & +145 \\ 090 & +9 & 274 & +77 \\ 106 & +32 & 313 & +46 \\ 124 & +17 & 326 & +9\end{array}$

with standard deviation $26^{\circ}$. The figures are in close agreement with many open ocean records, e.g. at the ocean weather ship station 'I' (Hay, I954), where eighteen observations, each of 5 days' duration, showed a deflexion of $42^{\circ}$ with standard deviation $42^{\circ}$. For comparison, current sets were related to winds recorded during the $24 \mathrm{~h}$ preceding each observation, wind data being obtained from 3-hourly readings of an anemometer at Tynemouth. The relationship here was less good, with deflexion $20^{\circ}$ and standard deviation $59^{\circ}$. From this it seems likely that the onset of a given wind and the appearance of the induced current are separated in time by only a very few hours.

A relationship can also be established between wind and current speeds using the data in columns 3 and 5 of Table I. For all observations $U_{s}=\mathrm{I} \cdot 30$ miles per half lunar day, $U_{a}=67$ miles per half lunar day, where $U_{s}$ represents residual current velocity and $U_{a}$ residual wind velocity.

Following Thorade (Proudman, I953, p. I76) and employing a mean latitude $(\phi)$ of $55^{\circ} 06^{\prime} \mathrm{N}$. we obtain the equation

$$
\frac{U_{s}(\sin \phi)^{\frac{1}{2}}}{U_{a}}=0.018 .
$$

For this expression Thorade found the value 0.0126 and Ekman 0.019.

There appears to be no basic current independent of wind such as has been found in the southern North Sea from an analysis of lightship current records (Lawford \& Veley, 1955). 
With regard to the five observations which were excluded from the deflexion calculations, if the mean deflexion is applied to each wind all the sets become onshore, for between the Tyne and Newbiggin the trend of the coast is about north-west to south-east. But only very small onshore sets were recorded; potential onshore sets, then, are deflected by the coastline, those to the south of south-west being deflected anticlockwise and those to the north of south-west clockwise.

Throughout this account it has been assumed that the current observations were made during a fair sample of the wind speeds experienced during the year. Table 3 shows that this is approximately true. Wind-speed estimations

TABLE 3. 9 A.M. WIND FORCES AT CULLERCOATS AND AT SEA, EXPRESSED AS PERCENTAGE OF TOTAL OBSERVATIONS

$\begin{array}{crcr} & & \text { At Cullercoats } & \text { At sea } \\ \text { Observations } & \ldots & 237 & 20 \\ \text { Calm } & & \mathrm{I} \cdot 7 & 0 \\ \text { Force I } & & 12 \cdot 2 & 15 \\ \text { Force 2 } & & 2 \mathrm{I} \cdot 7 & 25 \\ \text { Force 3 } & & 26 \cdot 2 & 20 \\ \text { Force 4 } & & 19 \cdot 4 & 25 \\ \text { Force 5 } & & \text { IO. } & \text { I0 } \\ \text { Force 6 } & & 5 \cdot 9 & 0 \\ \text { Force 7 } & & 2 \cdot \mathrm{I} & 5\end{array}$

TABLE 4. 9 A.M. WIND DIRECTIONS AT CULLERCOATS AND AT SEA, EXPRESSED AS PERCENTAGE OF TOTAL OBSERVATIONS

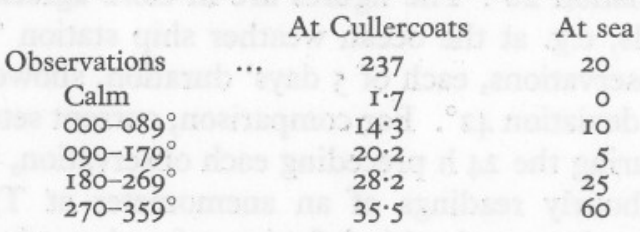

made on the 20 sea-going days at 9 a.m. are compared with estimations made at corresponding times at Cullercoats on 237 occasions. Wind directions (Table 4) do not correspond so closely, and it is clear that too many north-west winds and too few south-east winds are represented in the sea observations. This has had a small effect on the figures given for residual and predominant currents; if a residual current is worked for the 237 shore observations and a deflexion of $+2 \mathrm{I}^{\circ}$ is allowed, as was found for residual winds and currents at sea the result, using Thorade's formula, is $110^{\circ}, 0.06 \mathrm{knot}$, which is not very different from the II $4^{\circ}$, O.I knot already found.

Finally, an answer must be given to the question of whether the buoy used in the investigations was seriously affected by the wind. It would be simple to discover this by attaching a current meter to the drogue, when the total reading would be due to wind drift, but for the very low speeds (certainly less than Io ft a minute) which would have to be measured in a horizontal direction alone; so this solution is impracticable at sea. It might have been 
possible to test the buoy's downwind movement in one of the Tyne docks were it not suspected that the dock water itself is always in slow motion. Short of wind tunnel experiments I was forced to fall back on observation and inference from the buoy's movement at sea.

In low winds I examined the drogue underwater. It hung down vertically from the buoy and did not move away from small fragments of paper which I placed near it. In high winds direct underwater observation was not possible but the buoy's track was often so far away from downwind as to make it seem unlikely that it was carrying much leeway. Attention is drawn to the record of I9 June, where a westerly wind of force six blew for more than $6 \mathrm{~h}$. The buoy ran $5 \mathrm{I}^{\circ}$ to the right of downwind and parallel to the coast. Unless leeway was being cancelled by a large onshore current, already seen to be very unlikely, this track represents true water movement. Even in a strong breeze, then, leeway is negligible.

My acknowledgements are due to the Tyne Improvement Commissioners for access to tide gauge information at South Shields, to the Coast Guards of Tynemouth for providing wind records and to Dr H. O. Bull and Dr J. N. Carruthers for valued advice. Especially is my gratitude due to R. Harrison, skipper of the R.V. Alexander Meek of the Dove Marine Laboratory, for the many patient hours he spent at sea with me in all weathers on this work.

\section{SUMMARY}

Observations have been made of the surface currents off the Northumberland coast over a period of 12 months, using a free-floating buoy. A mean vector current was found, setting II $4^{\circ}$ at 0.1 knot. Currents flowed into the quadrant to the right of downwind except when this would have directed them ashore. A relationship is established between wind speed and current speed.

\section{REFERENCES}

FultoN, T. W., I897. The currents of the North Sea, and their relation to fisheries. Rep. Fish. Bd Scot., 15th Year (1896), Pt. III, pp. 334-98.

HAY, R. F. M., 1954. A verification of Ekman's theory relating wind and ocean current directions using ocean weather ships' data. Mar. Obs., Vol. 24, pp. 226-30.

LAWFORD, A. L. \& Veley, V. F. C., 1955. The relationship between local wind and current in coastal waters of the British Isles. National Institute of Oceanography, Internal Report, No. A3.

Meek, A., I926. The currents of the East Coast. Rep. Dove mar. Lab., Vol. I5, pp. 38-42.

Proudman, J., 1953. Dynamical Oceanography. London: Methuen.

TAIT, J. B., I930. The surface water drift in the northern and middle areas of the North Sea and in the Faroe-Shetland channel. Part I. Sci. Invest., Fish. Bd Scot., I930, No. 2, 82 pp.

- 1937. The surface water drift in the northern and middle areas of the North Sea and in the Faroe-Shetland channel. Part 2. Section 3. Sci. Invest., Fish. Bd Scot., 1937, No. I. 